\begin{abstract}
The fishery for Pacific hake (Merluccius productus) was established in the northern Gulf of California (NGC) in Mexico in 2000. To describe relevant features of the fishery and biology of Pacific hake, we analyzed 5 years of data from an on board observers program. Using generalized additive models, we standardized catch per unit of effort (CPUE), mean standard length (SL), and sex ratio. Also, we investigated by year the joint effect of maturity stage and sex on size distribution, biometric relationships, and the effect of maturity stage (juvenile or adult) on sex ratio. For all characteristics, significant interannual variability was observed. An average decrease was observed both in CPUE (52\%) and mean SL (7\%) during January-March. Adult males were more abundant in catch, with a male-tofemale ratio of 1.12:1.00 $(P<0.05)$, and adult females were larger than males $(F=807.09, P<0.05)$. Our results support the previously suggested hypothesis that the NGC is the winter spawning ground for Pacific hake in the region. Further research is needed to determine the status of the stock in the NGC and to outline specific potential management strategies.
\end{abstract}

\section{Catch rate, length, and sex ratio of Pacific hake (Mer/uccius productus) in the northern Gulf of California}

\author{
Oscar G. Zamora-García' \\ J. Fernando Márquez-Farías \\ (contact author) $^{2}$ \\ Carlos Díaz-Avalos ${ }^{4}$ \\ Noemí I. Zamora-García ${ }^{5}$ \\ Raúl E. Lara-Mendoza ${ }^{6}$
}

Aristóteles Stavrinaky-Suárez ${ }^{3}$

Email address for contact author: fmarquez@uas.edu.mx

${ }^{1}$ Posgrado en Ciencias del Mar y Limnología Universidad Nacional Autónoma de Mexico Avenida Ciudad Universitaria 3000 04510 Coyoacán, Mexico City, Mexico

${ }^{2}$ Facultad de Ciencias del Mar Universidad Autónoma de Sinaloa Paseo Claussen $s / n$ Colonia Los Pinos 82000 Mazatlán, Sinaloa, Mexico

${ }^{3}$ Environmental Defense Fund de Mexico Surfrider Way 5701 Goleta, California 93117

${ }^{4}$ Departamento de Probabilidad y Estadística Instituto de Investigaciones en Matemáticas Aplicadas y en Sistemas Universidad Nacional Autónoma de Mexico Circuito Escolar s/n, Ciudad Universitaria 04510 Coyoacán, Mexico City, Mexico

\author{
${ }^{5}$ Comisión Nacional de Acuacultura y Pesca \\ Secretaria de Agricultura y Desarrollo Rural \\ Avenida Camarón Sábalo 1210 \\ 82100 Mazatlán, Sinaloa, Mexico \\ ${ }^{6}$ Dirección General Adjunta de Investigación \\ Pesquera en el Atlántico \\ Instituto Nacional de Pesca y Acuacultura \\ Secretaría de Agricultura y Desarrollo Rural, \\ Avenida Mexico 190 \\ Colonia del Carmen \\ 04100 Coyoacán, Mexico City, Mexico.
}

Manuscript submitted 31 January 2020. Manuscript accepted 17 November 2020. Fish. Bull. 118:365-379 (2020). Online publication date: 17 December 2020. doi: 10.7755/FB.118.4.6

The views and opinions expressed or implied in this article are those of the author (or authors) and do not necessarily reflect the position of the National Marine Fisheries Service, NOAA.
The Pacific hake (Merluccius productus) is the most productive and economically important fish species on the west coasts of the United States and Canada (Hamel et al., 2015), with landings exceeding 400,000 metric tons (t) in recent years (Grandin et al., 2020). This species is distributed from the Gulf of Alaska to Costa Rica, including the Gulf of California (Lloris et al., 2003). In Mexico, early estimates of biomass of Pacific hake in the northern Gulf of California (NGC) ranged from 30,000 to 65,000 t (Mathews et al., 1974; PadillaGarcía, 1981), and the maximum sustainable yield was 2288-11,453 t. Despite the known abundance of Pacific hake, trawlers licensed to catch shrimp and finfish species were not interested in commercial use of Pacific hake until the late 1990s (Ramírez-Rodríguez, 2017). Total landings of Pacific hake have ranged from $197 \mathrm{t}$ (in 2000) to a peak of $6628 \mathrm{t}$ (in 2014), with a mean of approximately $2225 \mathrm{t}$ for 2000-2019 in the NGC (Fig. 1).

The Pacific hake, one of the most abundant fish species in the California Current Large Marine Ecosystem, plays a significant ecological role as a link between species of low (euphausiids) and high (sharks and seals) trophic levels (Ressler et al., 2007). Because of the commercial importance of this demersal species, its biological, ecological, migratory, and fishery traits have been widely 


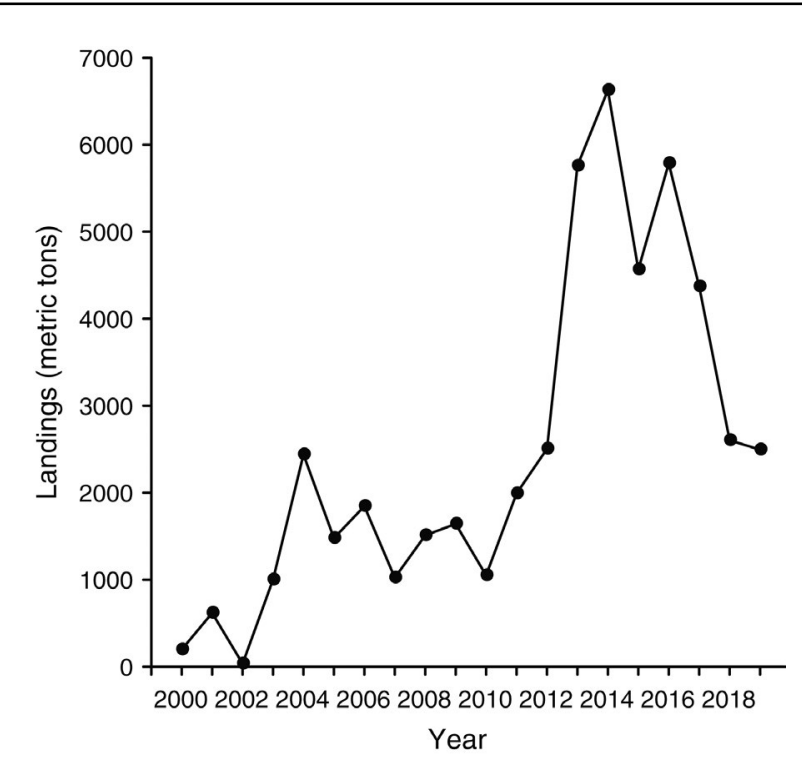

Figure 1

Annual landings of Pacific hake (Merluccius productus) from the northern Gulf of California in Mexico during 20002019, in metric tons, from the Mexico National Aquaculture and Fishing Commission database of landing notifications. Data for 2019 include landings only up to 4 September.

studied in the United States and Canada (McFarlane and Beamish, 1985; Smith et al., 1992; Saunders and McFarlane, 1997; Benson et al., 2002; King et al., 2012). However, studies of Pacific hake in Mexico are few and scattered.

The government of Mexico began issuing permits for the commercial catch of Pacific hake in 2018 to states around the Gulf of California (Sonora, Baja California, and Sinaloa). Currently, the only rule to control fishing effort is a limit of the number of permits to 80 (DOF, 2018). The fishing season for this species occurs, on average, during winter and spring (January-March) each year, and the largest portion of landings come from Sonora.

Little is known about the biology and population dynamics of Pacific hake in the NGC. It has been hypothesized that this population belongs to a different species, the Cortez hake (M. hernandezi) (Mathews, 1985), mainly because of its maximum size of $107 \mathrm{~cm}$ total length (TL), much larger than that of the unfished population of what had been considered Panama hake ( $M$. angustimanus), a species that was also called the dwarf hake, from the southern Gulf of California and Baja California Sur (33.5 cm TL) (Mathews, 1975; Balart-Páez, 2005). Nevertheless, results from molecular and meristic studies indicate the presence of a single species, $M$. productus, in North America with different population units (Silva-Segundo et al., 2011; García-De León et al., 2018).

This study aimed to describe relevant features of the fishery and biology of the Pacific hake caught in the NGC. We report for the first time the variability of catch rates and population structure, by length and sex, of this species in this region, as well as the morphometric relationships (length-weight and length-length). This information can be used as a baseline for future stock assessments and fisheries management.

\section{Materials and methods}

\section{Data and sample collection}

The fishery was monitored by an on board observer program from 2015 through 2019 during the January-March fishing season with a percentage of coverage of total trips ranging from 5\% (in 2016) to 12\% (in 2019). The fleet that targeted Pacific hake was based in Puerto Peñasco $(76 \%)$ and Guaymas (12\%), Sonora; Mazatlán, Sinaloa (8\%); and San Felipe, Baja California (4\%). During 77 trips on board 25 commercial ships, 817 trawl tows were completed.

The fishery used diurnal bottom trawling, and vessels deployed trawl net sets from 0600 to 1800 . The width of the net mouth was $30 \mathrm{~m}$ on average and opened vertically (to about $4 \mathrm{~m}$ ) as a result of a floating line in the top rope and a ballast chain in the lower rope of about $450 \mathrm{~kg}$. The mesh size in the codend of nets ranged from 6.35 to $12.70 \mathrm{~cm}(2.5-5.0 \mathrm{in})$, and the most common (89\%) mesh sizes were $10.16 \mathrm{~cm}(58 \%), 7.62 \mathrm{~cm}(18 \%)$, and $8.89 \mathrm{~cm}$ (13\%). The average speed and duration of trawl tows were $4.37 \mathrm{~km} / \mathrm{h}$ (standard deviation [SD] 0.55) $(2.36 \mathrm{kt}$ [SD 0.30]) and $3.53 \mathrm{~h}$ (SD 1.27), respectively. The depth of trawl tows varied, with a range of 111-335 m and a mean of $253.2 \mathrm{~m}$ (SD 28.75). Trawl tows followed the slope of the Delfín Basin, always south of the Upper Gulf of California and Colorado River Delta Biosphere Reserve and a refuge for vaquitas (Phocoena sinus) in a fishing zone called the horseshoe by fishermen because of its shape (Fig. 2).

On board fishing vessels, fishermen head and gut Pacific hake. A total of 2853 Pacific hake were weighed before and after processing. We estimated that an average of $38.74 \%$ (SD 7.30) of total weight was lost during processing. Then, to account for the percentage of loss, the processed weight was multiplied by a conversion factor $\left(\mathrm{FAO}^{1}\right)$ of 1.65 (SD 0.19).

After processing, fish are arranged in plastic boxes that weigh $\sim 70 \mathrm{~kg}$, washed with seawater, and stored between ice layers in the cargo hold. During this process, small $(<40 \mathrm{~cm} \mathrm{TL})$ and damaged Pacific hake are discarded. Nominal catch (NC) of Pacific hake per tow was estimated with the following equation:

$$
N C=C F(B \times W)+D,
$$

where $C F=$ the conversion factor needed to estimate live weight from Pacific hake gutted and headed;

$B=$ the number of boxes stored;

$W=$ the weight of each box $(\sim 70 \mathrm{~kg})$; and

$D=$ an observer's estimate of the weight of Pacific hake discarded.

\footnotetext{
${ }^{1}$ FAO. 2000. Conversion factors: landed weight to live weight. FAO Fish. Circ. 847, 176 p. FAO, Rome. [Available from website.]
} 


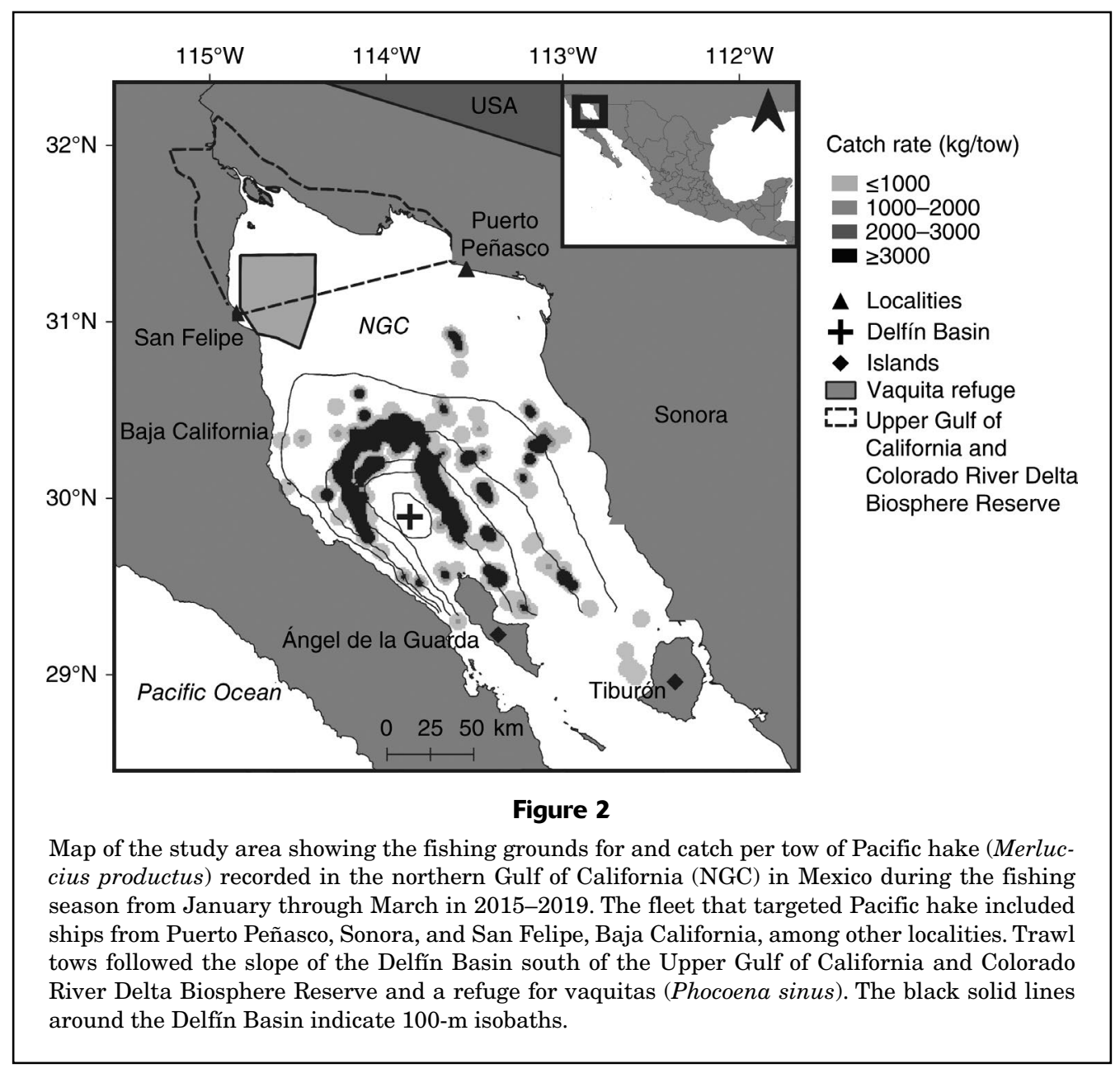

The NC was divided by the duration of the trawl tow (from the end of net launch until the start of net collection), to obtain the catch rate, or catch per unit of effort (CPUE), in kilograms per hour.

Observers recorded biometrics, including standard length (SL) and total fresh weight, from $\sim 60 \%$ of tows per trip: 98 of 131 trips in 2015, 69 of 118 trips in 2016, 93 of 181 trips in 2017, 105 of 170 trips in 2018, and 108 of 217 trips in 2019. They selected random samples of fish (maximum of 100 fish per set) and identified them to species following Lloris et al. (2003). Standard length of fish was measured from the tip of the mouth to the caudal peduncle to the nearest $0.1 \mathrm{~cm}$. Total fresh weight was measured by using a digital balance with an accuracy of $1 \mathrm{~g}$. The specimens were dissected to determine sex and maturity stages. We used a 5-stage morpho-chromatic key to determine the maturity of Pacific hake, according to Holden and Raitt (1975): immature (stage 1), developing (stage 2), mature (stage 3), spawning (stage 4), and postspawning or spent (stage 5). To ease comparisons, we considered fish that had signs of recent, current, or imminent spawning (stages 3-5) to be adults. Fish assigned to stages 1 and 2 were considered juveniles.

\section{Data analysis}

Catch rate standardization From all the trawl tows completed (number of tows $[n]=817$ ), we excluded 3 tows because of gear malfunction, according to Maunder and Punt (2004), and 9 tows completed in April 2019 because of incomparability. A log-transformed index of catch per unit of effort (logCPUE) of the positive values (number of values=805) was used for hypothesis testing because these values followed a log-normal-like frequency distribution. The geometric mean was used as the index for mean CPUE.

First, we developed generalized linear models (GLMs) to test the effect of the selected explanatory variables. However, we found several nonlinear effects, a result that violates the main assumption of GLMs. Then, we used generalized additive models (GAMs), which are semiparametric extensions of GLMs with an additive predictor (Guisan et al., 2002), to identify significant explanatory variables (speed of trawl, mesh size in the codend, depth, and the hour of the day, month, and year) and the nature of the relationships with the logCPUE. We considered a normal probability distribution of 
logCPUE and used its canonical link function (identity), meaning that a proportional rate of change between the set of explanatory variables and logCPUE was expected, and we evaluated each model's residuals to verify compliance with assumptions. To avoid confounding effects, we tested multicollinearity in explanatory variables through tests of correlation and analysis of variance inflating factors. We used only variables with variance inflating factors <3 (Zuur et al., 2009). Model formulations were tested according to our previous knowledge of the system. Stepwise addition of terms was conducted, and we kept only variables that reduced the Akaike information criterion (AIC) by at least 2 units and that had a significant increase of explained deviance (Marín-Enríquez et al., 2020). Also, variables with effective degrees of freedom greater than 8 were excluded because they are considered highly nonlinear and difficult to interpret (Zuur et al., 2009). The model with the lowest AIC was considered the best (Burnham and Anderson, 2004). Equal fishing power for the entire fleet was assumed.

Variability of length and sex composition The length and sex composition of the catch of Pacific hake were assessed by using a 2-step approach. First, using GAMs, we repeated the analysis previously described to identify significant explanatory variables and the nature of the relationship. For this purpose, we used only tows for which biometrics were recorded $(n=469)$ and estimated the mean SL and sex ratio for each one. An index of the natural logarithms of sex ratios (logSR) and mean SL were used as response variables of the GAMs.

The second step involved a detailed analysis of the distribution of SL in catch related to the factors of sex and maturity stage (juvenile or adult) by using a 2-way analysis of variance with interaction. For significant effects, we included the year factor to evaluate temporal consistency. A Tukey's honestly significant difference test was carried out to identify level-specific differences.

Also, we performed a set of chi-square tests to examine significant departures from the null hypothesis of an equal sex ratio (ratio of the number of males to the number of females: 1:1) according to Zar (1999).

Biometric relationships The length-weight relationship (LWR) was estimated by fitting a power model:

$$
T W=a(S L)^{\mathrm{b}},
$$

where $T W=$ the total weight (in grams);

$a=$ the intercept; and

$b=$ the slope (allometric coefficient).

Models were fit hierarchically to each data set for Pacific hake caught in this study, starting with the full data set and continuing with data sets for each sex, maturity stage, and year. Parameter optimization for each model was conducted by minimizing the residual sum of squares (RSS). Statistical differences in the LWR by sex, maturity stage, and year were assessed by a series of "extra sum of squares" tests (Ritz and Streibig, 2008) defined by the following equation:

$$
F=\frac{\left(R S S_{0}\left(\beta_{0}\right)-R S S_{1}\left(\beta_{1}\right)\right) /\left(d f_{0}-d f_{1}\right)}{R S S_{1} / d f_{1}},
$$

where $F=$ the Fisher's parameter;

$d f=$ the degrees of freedom;

$\beta_{0}=$ the nested model; and

$\beta_{1}=$ subset of each model.

To describe the relationships of TL and fork length (FL) to $\mathrm{SL}$, we used linear regression models:

$$
y=a+b(S L)
$$

where $y=$ TL or FL.

Pearson's correlation coefficient $(r)$ was used to evaluate the level of association of each pair of variables. The existence of differences between males and females for each relationship was determined by using analysis of covariance.

All data and statistical analyses were carried out by using a significance level of 0.05, Microsoft Excel ${ }^{2} 2016$ (Microsoft Corp., Redmond, WA), and statistical software R, vers. 3.6.1 (R Core Team, 2019).

\section{Results}

\section{Catch rate standardization}

Year and the interaction of month and year were the most important variables (explained $10.69 \%$ of total deviance). Also, nonlinear effects (explained by smoothers) were found between tow speed, mesh size of trawl net, depth of tow, and hour of the day of tow in logCPUE (Table 1). The final model explained $19.9 \%$ of the total deviance. Levels of CPUE were higher during tows with speeds of $3.50-4.70 \mathrm{~km} / \mathrm{h}(1.89-2.54 \mathrm{kt})$ and declined inversely with speed (Fig. 3A). Tows of trawl nets with mesh sizes of 7.62-8.16 cm (3.00-3.25 in) had the highest CPUE values, followed by tows of nets with mesh sizes of 9.80-10.00 cm (Fig. 3B). Values of CPUE remained mostly stable with depth. However, lower CPUE levels were observed for tows at depths $>280 \mathrm{~m}$, with a consequent increase in the uncertainty (Fig. 3C). The highest CPUE values were recorded during the morning from 0800 to 1000 with a significant decrease beginning after 1400 (Fig. 3D).

Estimated mean CPUE was the highest in 2015 with $633 \mathrm{~kg} / \mathrm{h}$ (95\% confidence interval [CI]: 484-830 kg/h) and the lowest in 2016 with $199 \mathrm{~kg} / \mathrm{h}$ (95\% CI: 158-250 kg/h), and estimates indicate less variability for $2017(529 \mathrm{~kg} / \mathrm{h}[95 \%$ CI: $368-773$ kg/h]), 2018 (379 kg/h [95\% CI: 310-464 kg/h]),

\footnotetext{
${ }^{2}$ Mention of trade names or commercial companies is for identification purposes only and does not imply endorsement by the National Marine Fisheries Service, NOAA.
} 


\begin{tabular}{|c|c|c|c|c|c|}
\hline \multicolumn{6}{|c|}{ Table 1} \\
\hline \multicolumn{6}{|c|}{$\begin{array}{l}\text { Summary of variables in the generalized additive models used to standardize the natura } \\
\text { logarithm of catch per unit of effort (logCPUE), the mean standard length (SL), and the nat } \\
\text { ural logarithm of the sex ratio (logSR) for Pacific hake (Merluccius productus) in the north } \\
\text { ern Gulf of California. The model with the lowest Akaike information criterion (AIC) was } \\
\text { considered the best. Also provided are the differences in AIC values between the best mode } \\
\text { and each of the other models ( } \triangle \mathrm{AICs} \text { ). The explanatory variables used in the models include } \\
\text { tow speed (in kilometers per hour), mesh size in the codend (in centimeters), average depth } \\
\text { of trawl tow (in meters), hour of the beginning of the tow (with hours expressed as numeral } \\
\text { between } 1 \text { and } 24 \text { ), month, year, and the interaction of month and year. Models were fit to } \\
\text { data for Pacific hake caught in } 2015-2019 \text { during the fishing season from January through } \\
\text { March. Asterisks }(*) \text { indicate variables that were excluded from the final models because } \\
\text { their inclusion did not reduce AIC in at least } 2 \text { units along with a significant increase in the } \\
\text { explained variance. The variable hour in the model for mean SL was excluded because it } \\
\text { had high nonlinearity (effective degrees of freedom }=8.59 \text { ), considered difficult to interpret. }\end{array}$} \\
\hline $\begin{array}{l}\text { Response } \\
\text { variable }\end{array}$ & $\begin{array}{l}\text { Explanatory } \\
\text { variable }\end{array}$ & $\begin{array}{c}\text { Explained } \\
\text { deviance (\%) }\end{array}$ & $\begin{array}{c}\text { Cummulative } \\
\text { deviance } \\
\text { explained }(\%)\end{array}$ & $\mathrm{AIC}$ & $\Delta \mathrm{AIC}$ \\
\hline \multirow[t]{10}{*}{ logCPUE } & $\begin{array}{l}\text { Null } \\
\text { Covariates }\end{array}$ & 0.00 & 0.00 & 2603.70 & \\
\hline & $+\mathrm{s}($ Speed $)$ & 2.43 & 2.43 & 2598.48 & -5.22 \\
\hline & $+\mathrm{s}(\mathrm{Mesh})$ & 3.69 & 6.12 & 2580.93 & -17.55 \\
\hline & $+\mathrm{s}($ Depth $)$ & 2.04 & 8.16 & 2571.97 & -8.96 \\
\hline & $+\mathrm{s}($ Hour $)$ & 1.05 & 9.21 & 2454.34 & -117.63 \\
\hline & Factors & & & & \\
\hline & + Month & 1.09 & 10.30 & 2449.98 & -4.36 \\
\hline & + Year & 2.10 & 12.40 & 2439.75 & -10.23 \\
\hline & Interactions & & & & \\
\hline & + Month $\times$ Year & 7.50 & 19.90 & 2380.46 & -59.29 \\
\hline \multirow[t]{11}{*}{ Mean SL } & Null & 0.00 & 0.00 & 3505.75 & \\
\hline & Covariates & & & & \\
\hline & $+\mathrm{s}(\mathrm{Mesh})^{*}$ & 0.17 & & 3505.59 & -0.15 \\
\hline & $+\mathrm{s}(\text { Hour })^{*}$ & 4.35 & & 3391.07 & -114.68 \\
\hline & +s(Speed $)$ & 8.68 & 8.68 & 3473.78 & -32.97 \\
\hline & $+\mathrm{s}(\text { Depth })^{*}$ & 1.32 & & 3472.30 & -1.47 \\
\hline & Factors & & & & \\
\hline & +Month & 4.40 & 11.70 & 3460.61 & -13.71 \\
\hline & +Year & 4.60 & 15.00 & 3448.03 & -12.53 \\
\hline & Interactions & & & & \\
\hline & + Month $\times$ year* & 1.90 & & 3449.56 & +1.41 \\
\hline \multirow[t]{11}{*}{$\log S R$} & Null & 0.00 & 0.00 & 1042.23 & \\
\hline & Covariates & & & & \\
\hline & $+\mathrm{s}(\operatorname{Mesh})^{*}$ & 2.40 & & 1042.15 & -0.08 \\
\hline & +s(Depth) & 4.90 & 4.90 & 1026.90 & -15.25 \\
\hline & $+\mathrm{s}($ Speed $) *$ & 2.43 & & 1026.00 & -0.90 \\
\hline & $+\mathrm{s}(\text { Hour })^{*}$ & 0.40 & & 985.29 & -40.71 \\
\hline & Factors & & & & \\
\hline & + Month* & -0.29 & & 1030.00 & -44.71 \\
\hline & + Year & 7.14 & 7.14 & 1024.37 & -2.53 \\
\hline & Interactions & & & & \\
\hline & + Month $\times$ year & 5.76 & 12.90 & 1013.30 & 11.08 \\
\hline
\end{tabular}

and 2019 (433 kg/h [95\% CI: 321-590 kg/h]) (Fig. 4A). In addition, a negative trend in CPUE was observed on a monthly basis (Fig. 4B). On average, January had the highest mean CPUE (719 kg/h [95\% CI: 493-1057 kg/h]), followed by significant decreases of $43 \%$ and $52 \%$ in
February (376 kg/h [95\% CI: 305-454 kg/h]) and March (312 kg/h [95\% CI: 253-385 kg/h]), respectively. However, this pattern was not consistent across years, as indicated by the relevance of the month and year interaction term (Table 1). 

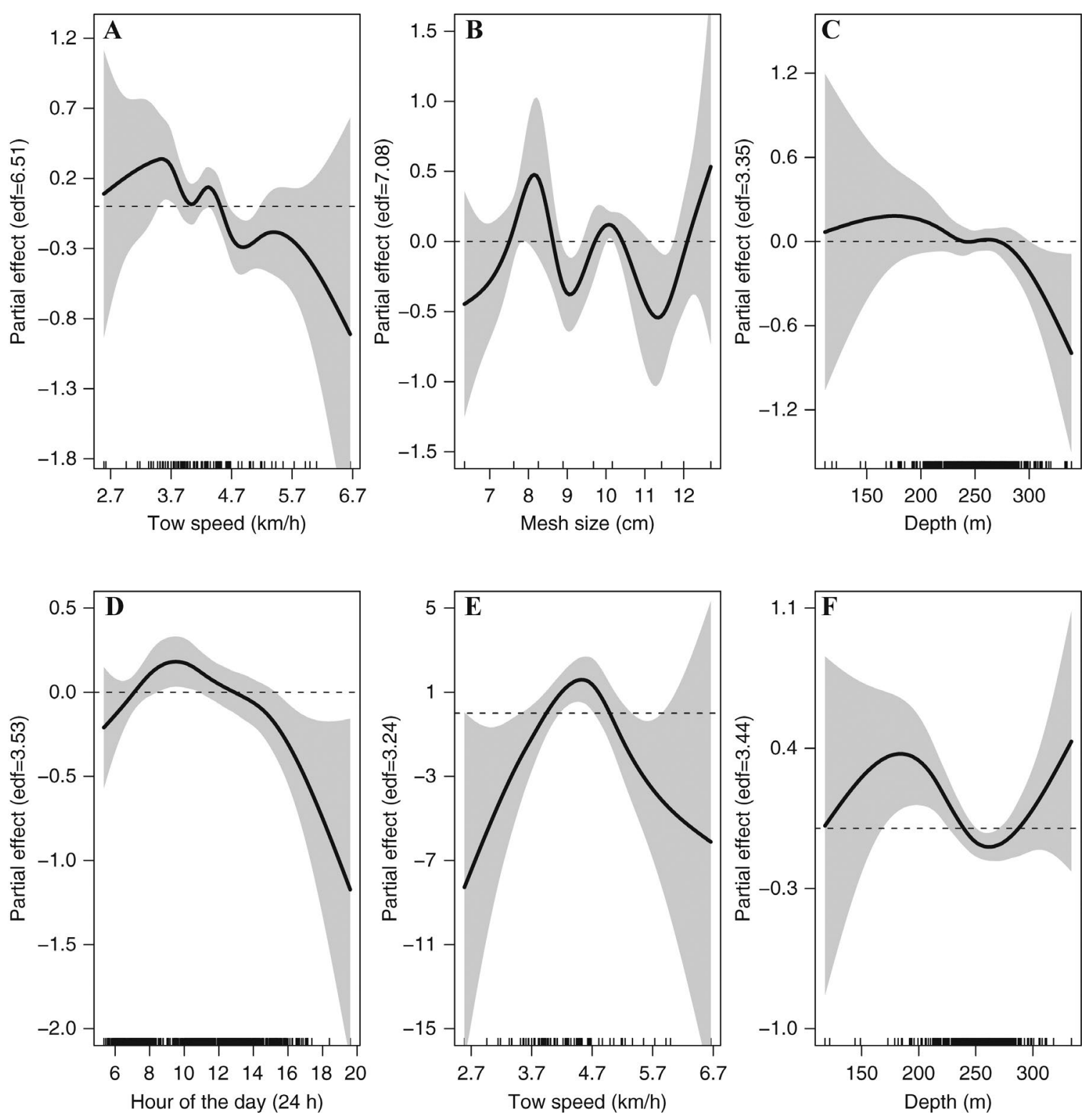

Figure 3

Partial effect plots of generalized additive models fit to the (A-D) natural logarithm of catch per unit of effort, (E) mean standard length, and (F) natural logarithm of sex ratio of Pacific hake (Merluccius productus) in the northern Gulf of California in Mexico. Explanatory variables in the models include speed of trawl tow, mesh size of trawl net, depth of trawl tow, and hour of the day of trawl tow (with hours expressed as numerals between 1 and 24). Data used in models are from Pacific hake caught in 2015-2019 during the fishing season from January through March. The gray shaded area in each plot represents the 95\% confidence interval, and black lines just above the x-axis represent the density of observations for each covariate. edf=effective degrees of freedom.

\section{Variability of mean length}

The final model for mean SL did not include mesh size, the hour of the day, or depth (Table 1). This model explained $15 \%$ of deviance and used just a smoother for tow speed as well as the factors of month and year without interaction. The smoother for speed indicates that tows made slower and faster than the interval of $4.00-5.00 \mathrm{~km} / \mathrm{h}$ (2.16-2.66 kt) caught Pacific hake with sizes under the mean SL of fish caught in this study (Fig. 3E).

The minimum annual mean SL occurred in 2015 (45.7 cm [95\% CI: $44.2-47.1 \mathrm{~cm}]$ ), and the maximum was observed in 2018 (51.8 cm [95\% CI: $50.5-53.2 \mathrm{~cm}])$. Although yearly differences in mean SL were significant 


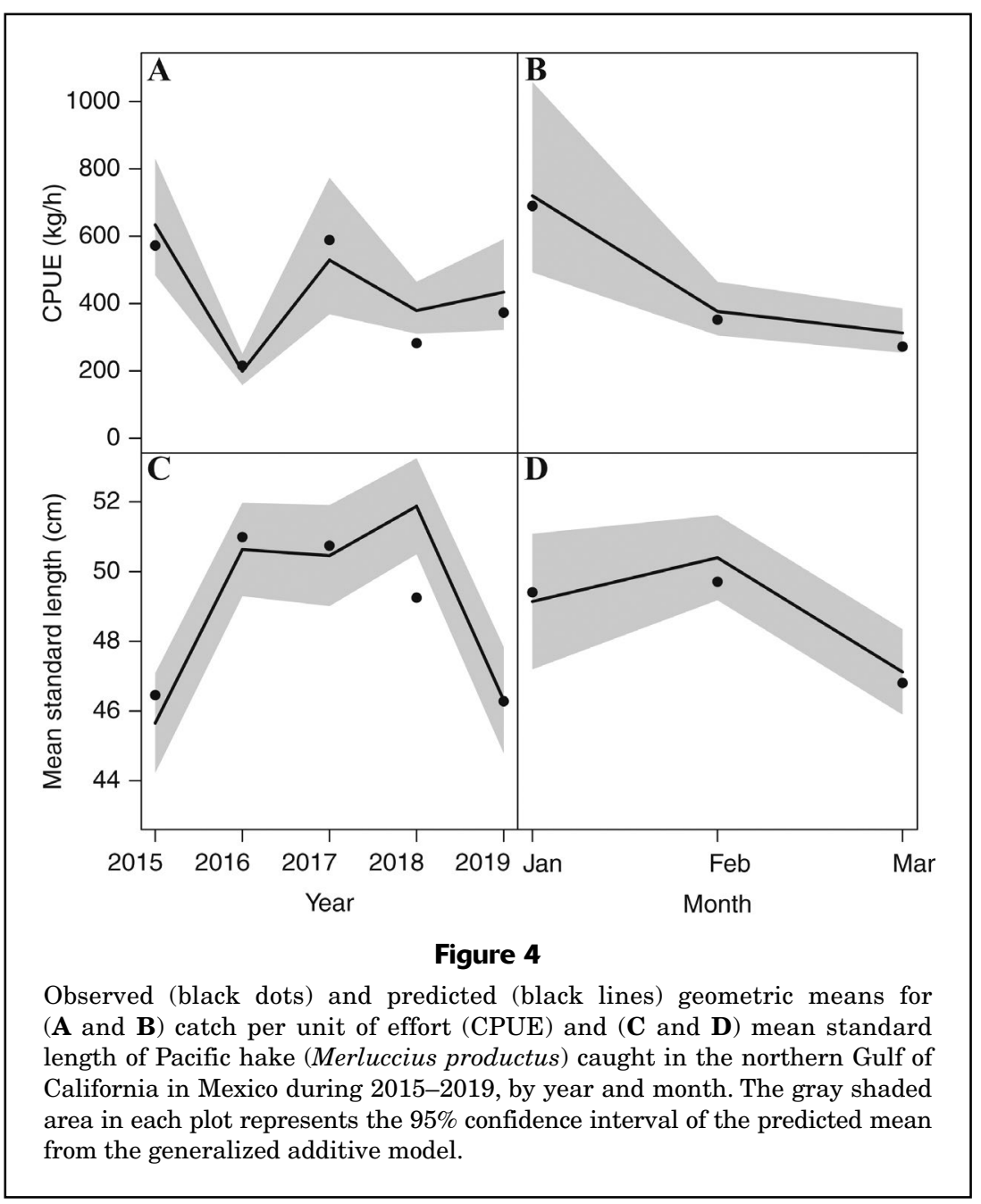

\section{Size distribution, sex ratio, and maturity}

The sizes of Pacific hake sampled ranged from 11.8 to $89.2 \mathrm{~cm}$ SL $(15.2-108.8 \mathrm{~cm}$ TL) with a mean of $47.49 \mathrm{~cm}$ SL (SD 13.7) (58.2 cm TL [SD 17.6]). During 2015-2017, the length-frequency distribution was bimodal. Pacific hake in the size class of 15-25 cm SL were most common, and fish in the size classes of $30-45 \mathrm{~cm}$ SL and 45-65-cm SL were caught in low numbers. In 2018 and 2019, a more normal distribution of SLs was observed with no clear size classes or flattened intervals. The dominant sex of Pacific hake at SLs $>70 \mathrm{~cm}$ was female, and females had significantly larger sizes $(F=807.09$, $P<0.05$ ) than males (Table 2, Fig. 5). As expected, adults had significantly higher SL than juveniles $(F=5174.49, P<0.05)$, and there was a trend across years ( $F=135.91, P<0.05)$.

Adults accounted for $72 \%$ of all sampled Pacific hake, $70 \%$ of females, and $73 \%$ of males. Results of the Tukey's honest significant difference test indicate that all mature females were significantly larger than mature males, and the difference was consistent across years. In 2015 (adjusted $P=0.99$ ) and 2019 (adjusted $P=0.99$ ), no difference was detected in SL between sexes in juveniles (Fig. 6).

Results from the series of chi-square tests indicate a male-skewed sex ratio for all sampled Pacific hake (male-tofemale ratio of 1.12:1.00, $P<0.05$ ), but

$(P<0.05)$, a specific trend in mean SL was not observed (Fig. 4C). The monthly variability of mean SL indicates that the highest mean SLs occurred during January $(49.1 \mathrm{~cm}$ [95\% CI: $47.2-51.1 \mathrm{~cm}])$ and February $(50.3 \mathrm{~cm}$ [95\% CI: $49.2-51.6 \mathrm{~cm}$ ]) and that CPUE decreased $7 \%$ by March (47.1 cm [95\% CI: $45.9-48.3 \mathrm{~cm}])$, as shown in Figure 4D.

\section{Variability of sex ratio}

The final model of logSR explained $12.9 \%$ of the total deviance. The GAM used only a smoother for depth and the parametric effect of year as well as the interaction of month and year (Table 1). Results from the use of a smoother of depth indicate that tows with male-biased catch were conducted at depths $<225 \mathrm{~m}$ and $>275 \mathrm{~m}$ and that, at depths of 225-275 m, logSR tended to be zero (1:1 male-to-female ratio) or below (Fig. 3F).

No difference was found between months in logSR, but a difference was observed between years. However, the relevance of the month and year interaction means that there is no consistent trend of change of logSR during the fishing season. particularly for adult specimens (male-to-female ratio of 1.16:1.00, $P<0.05)$. For juveniles, the sex ratio was 1.00:1.00 $(P=0.70)$. There was no specific annual trend in the sex ratio for juveniles, but for adults, there were significantly more males in 4 out of 5 years. In 2018, we observed a female-biased sex ratio for all sampled Pacific hake (male-to-female ratio of 0.91:1.00). However, data split by maturity stage indicate that the sex ratio of adults favored males (male-to-female ratio of 1.09:1.00) and that females were dominate among juveniles (maleto-female ratio of $0.36: 1.00)$. Although there was no significant bias in the sex ratio in $2019(P=0.09)$, males were still more abundant (Table 3 ).

\section{Biometric relationships}

We found differences in the LWR between years $(F=216.55$, $P<0.05)$. The highest allometric coefficient $(b)$ was estimated for 2015, followed by the lowest estimate for 2016; no differences were observed between 2016 and 2017 ( $F=1.96$, $P=0.34$ ). For 2018 and 2019, an increasing tendency was observed, but differences remained present $(F=86.81$, $P<0.05)$. Differences in the LWR by sex were found in the 


\section{Table 2}

Standard lengths and total weights of Pacific hake (Merluccius productus) caught in the northern Gulf of California during the fishing season from 2015 through 2019, by year and sex. Lengths and weights also are provided for all years and both sexes combined. $n=$ number of samples; $\mathrm{SD}=$ standard deviation.

\begin{tabular}{|c|c|c|c|c|c|c|}
\hline \multirow[b]{2}{*}{ Year } & \multirow[b]{2}{*}{ Sex } & \multirow[b]{2}{*}{$n$} & \multicolumn{2}{|c|}{ Standard length $(\mathrm{cm})$} & \multicolumn{2}{|c|}{ Total weight $(\mathrm{g})$} \\
\hline & & & Range & Mean (SD) & Range & Mean (SD) \\
\hline All & All & 18,207 & $11.8-89.2$ & $47.1(13.7)$ & $22.0-9823.0$ & $1489.9(1016.2)$ \\
\hline \multirow[t]{3}{*}{2015} & All & 7255 & $11.8-89.1$ & $44.8(14.7)$ & $22.0-9823.0$ & $1347.8(1021.0)$ \\
\hline & All & 3322 & $11.9-89.1$ & $46.7(16.1)$ & $25.0-9823.0$ & $1558.4(1228.1)$ \\
\hline & M & 3933 & $11.8-79.9$ & $43.2(13.3)$ & $22.0-7120.0$ & $1169.8(761.5)$ \\
\hline \multirow[t]{3}{*}{2016} & All & 2564 & $13.0-88.0$ & $51.7(12.3)$ & $26.4-7420.0$ & $1741.8(892.9)$ \\
\hline & $\mathrm{F}$ & 1097 & $14.0-88.0$ & $56.4(11.3)$ & $36.0-7420.0$ & $2148.9(1003.2)$ \\
\hline & $\mathrm{M}$ & 1467 & $13.0-79.0$ & $48.3(11.8)$ & $26.4-4607.0$ & $1442.5(657.8)$ \\
\hline \multirow[t]{3}{*}{2017} & All & 3129 & $14.3-89.2$ & $48.7(13.6)$ & $49.0-7970.0$ & $1547.4(919.5)$ \\
\hline & $\mathrm{F}$ & 1503 & $17.4-89.2$ & $51.0(14.0)$ & $79.0-7970.0$ & $1742.0(1036.8)$ \\
\hline & $\mathrm{M}$ & 1626 & $14.3-74.1$ & $46.6(12.9)$ & $49.0-4685.4$ & $1366.3(751.2)$ \\
\hline \multirow[t]{3}{*}{2018} & All & 3077 & $18.0-88.5$ & $49.6(12.0)$ & $47.0-8435.0$ & $1633.2(1075.7)$ \\
\hline & $\mathrm{F}$ & 1613 & $18.5-88.5$ & $52.4(13.0)$ & $57.0-8435.0$ & $1931.1(1266.4)$ \\
\hline & $\mathrm{M}$ & 1464 & $18.0-78.1$ & $46.4(10.0)$ & $47.0-4805.0$ & $1305.7(679.6)$ \\
\hline \multirow[t]{3}{*}{2019} & All & 2182 & $15.5-89.0$ & $45.8(12.0)$ & $57.2-8678.0$ & 1395.9 (1083.6) \\
\hline & $\mathrm{F}$ & 1059 & $16.6-89.0$ & $48.4(13.9)$ & $66.0-8678.0$ & 1691.5 (1358.1) \\
\hline & $\mathrm{M}$ & 1123 & $15.5-72.0$ & $43.3(9.60)$ & $57.2-4288.0$ & $1116.4(616.9)$ \\
\hline
\end{tabular}

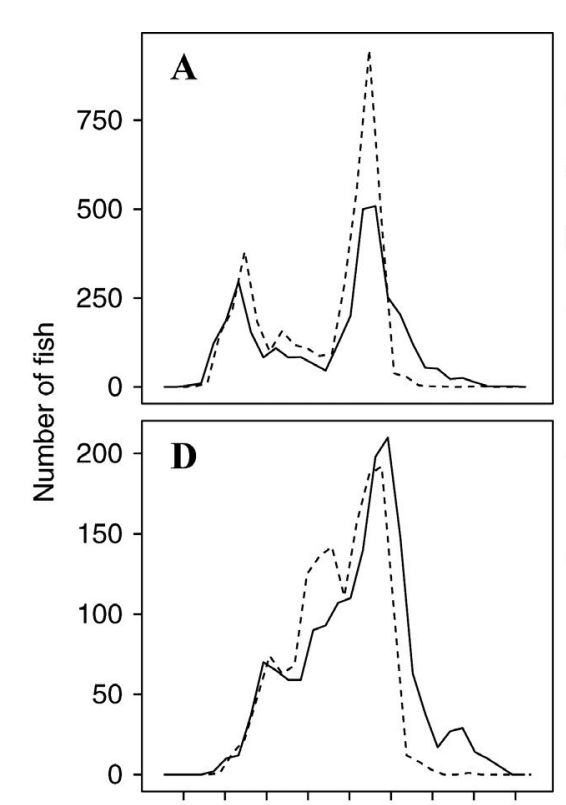

102030405060708090
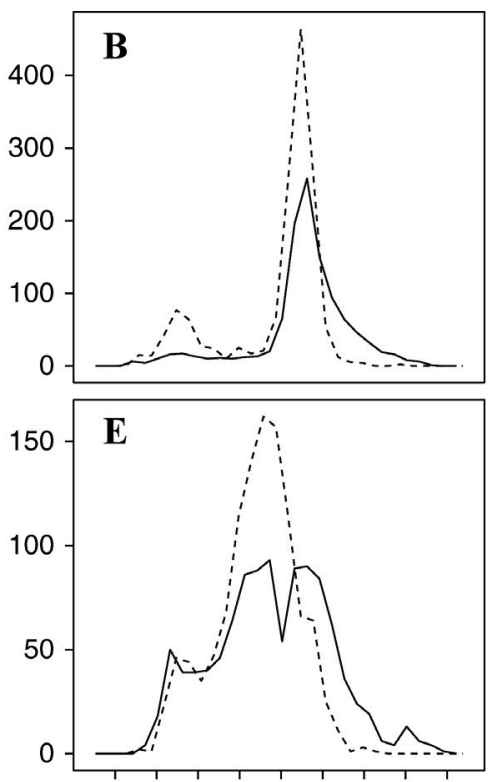

102030405060708090 Standard length $(\mathrm{cm})$

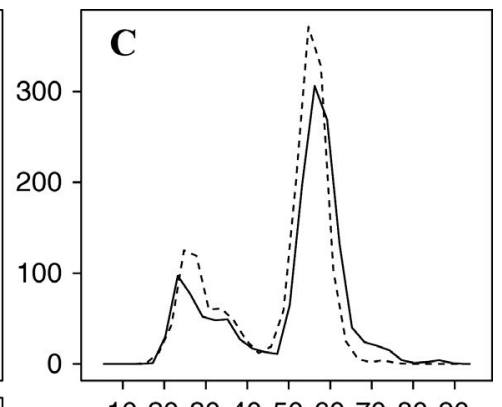

102030405060708090

Figure 5

Distribution of standard lengths of Pacific hake (Merluccius productus) caught in the northern Gulf of California in Mexico, by sex, during (A) 2015, (B) 2016, (C) 2017, (D) 2018, and (E) 2019. The solid and dashed lines in each panel represent lengths of females and males, respectively. 


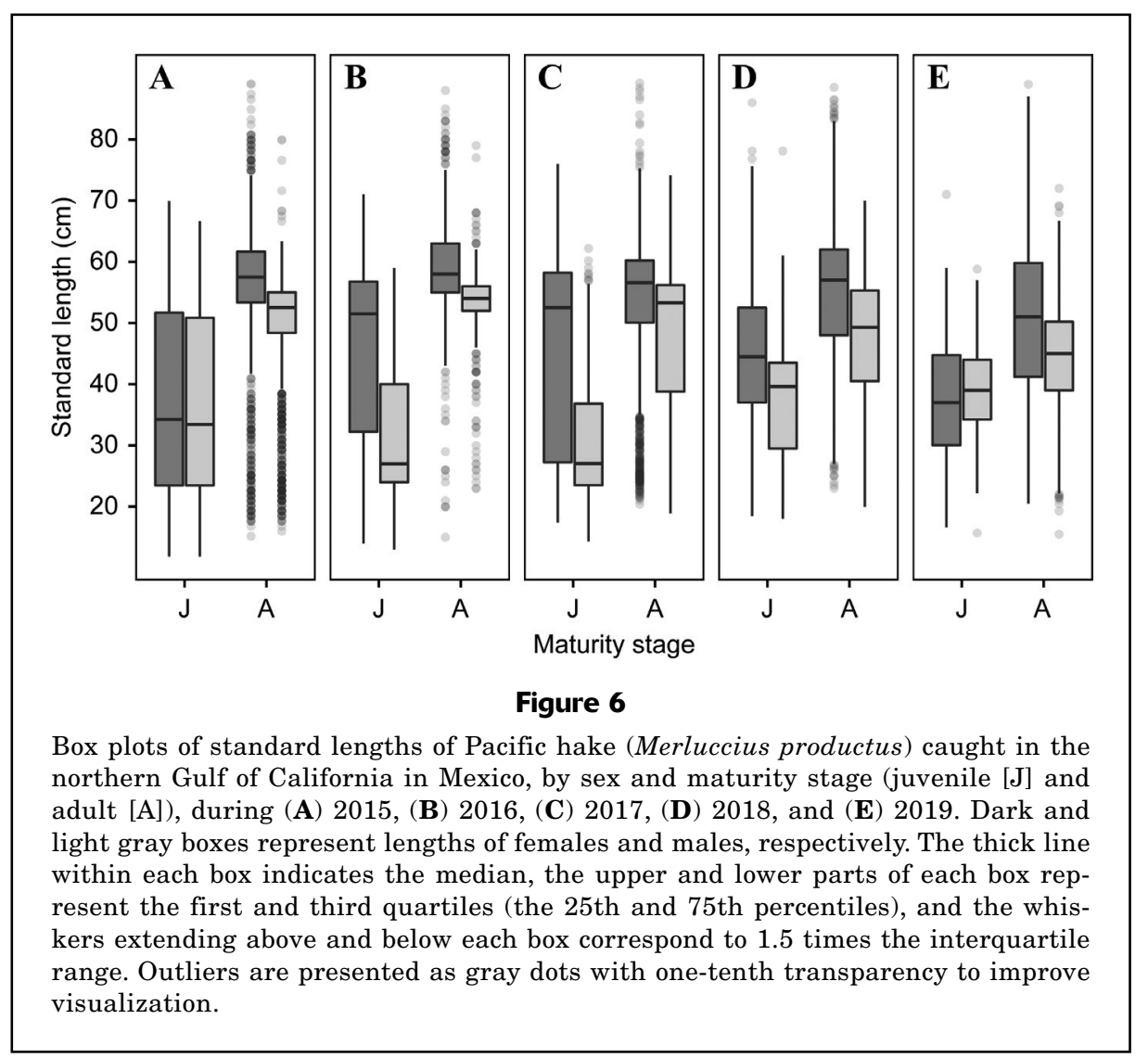

\section{Table 3}

Ratio of the number of males to the number of females, by maturity stage (juvenile $[\mathrm{J}]$ or adult $[\mathrm{A}]$ ) and by year, for Pacific hake (Merluccius productus) caught in the northern Gulf of California in 2015-2019. Sex ratios also are provided for all years and both maturity stages combined. The critical value for each chi-square $\left(\chi^{2}\right)$ test was 3.81. Asterisks (*) indicate significant departures from the null hypothesis of an equal sex ratio (a male-tofemale ratio of 1.00$)$. $\mathrm{M}=$ male; $\mathrm{F}=$ female; and $\mathrm{N}=$ none.

\begin{tabular}{lccrcc}
\hline Year & $\begin{array}{c}\text { Maturity } \\
\text { stage }\end{array}$ & $\begin{array}{c}\text { Sex } \\
\text { ratio }\end{array}$ & $\begin{array}{c}\text { Observed } \\
\chi^{2}\end{array}$ & $P$ & $\begin{array}{c}\text { Sex } \\
\text { bias }\end{array}$ \\
\hline All & Both & 1.12 & 57.03 & $<0.05^{*}$ & $\mathrm{M}$ \\
All & J & 1.01 & 0.15 & 0.70 & $\mathrm{~N}$ \\
All & $\mathrm{A}$ & 1.16 & 75.09 & $<0.05^{*}$ & $\mathrm{M}$ \\
2015 & $\mathrm{~J}$ & 1.15 & 15.66 & $<0.05^{*}$ & $\mathrm{M}$ \\
2016 & $\mathrm{~J}$ & 1.57 & 28.64 & $<0.05^{*}$ & $\mathrm{M}$ \\
2017 & $\mathrm{~J}$ & 0.69 & 12.63 & $<0.05^{*}$ & $\mathrm{~F}$ \\
2018 & $\mathrm{~J}$ & 0.36 & 120.37 & $<0.05^{*}$ & $\mathrm{~F}$ \\
2019 & $\mathrm{~J}$ & 0.94 & 0.23 & 0.63 & $\mathrm{~N}$ \\
2015 & $\mathrm{~A}$ & 1.22 & 37.36 & $<0.05^{*}$ & $\mathrm{M}$ \\
2016 & $\mathrm{~A}$ & 1.28 & 29.18 & $<0.05^{*}$ & $\mathrm{M}$ \\
2017 & $\mathrm{~A}$ & 1.15 & 13.40 & $<0.05^{*}$ & $\mathrm{M}$ \\
2018 & $\mathrm{~A}$ & 1.09 & 4.34 & $<0.05^{*}$ & $\mathrm{M}$ \\
2019 & $\mathrm{~A}$ & 1.08 & 2.72 & 0.09 & $\mathrm{~N}$ \\
& & & & & \\
\hline
\end{tabular}

general case - with all years pooled- $(F=129.16, P<0.05)$ and consistently in every single year evaluated (Table 4; Fig. 7, A-E). Similarly, the model fits for 2015 and 2018 were close to each other (Fig. 7F); even so, statistical differences were detected $(F=80.67, P<0.05)$. Females always had higher values of $b$ than males. However, no significant differences were found in the LWR between juveniles and adults $(F=0.72, P=0.97)$.

Both analyses of covariance revealed no significant effect of sex in the TL-SL $(P=0.22)$ and FL-SL $(P=0.49)$ relationships and a high level of correlation for both $(r>0.99)$. The resulting estimates of the regression parameters for the TL-SL relationship were 0.89 for $a$ and 1.21 for $b$, and estimates of the parameters for the FL-SL relationship were 0.51 for $a$ and 1.10 for $b$.

\section{Discussion}

Reports from previous studies have highlighted that the NGC is the winter spawning ground for the Pacific hake because its larvae are dominant in larval fish assemblages (Aceves-Medina et al., 2004; Sánchez-Velasco et al., 2009; Peiro-Alcantar et al., 2013). Also, the high proportion of adults in the catch in this zone $(70 \%)$ and the sudden increase of catch rates in a relatively limited area found in this study indicate that the fishery for Pacific hake 


\section{Table 4}

Estimated means of the parameters $a$ (intercept) and $b$ (slope or allometric coefficient) from the regression power model used for analysis of the length-weight relationship of Pacific hake (Merluccius productus) caught in the northern Gulf of California during the fishing season in 2015-2019, by year, sex, and maturity stage (juvenile $[\mathrm{J}]$ or adult $[\mathrm{A}]$ ). Estimates also are provided for all years, both sexes, and both maturity stages combined. Degrees of freedom (df), the coefficient of determination $\left(r^{2}\right)$, and the standard error of the mean (SE) are provided for each estimate.

\begin{tabular}{lccrccc}
\hline & & & & \multicolumn{2}{c}{ Regression parameter } \\
\cline { 5 - 7 } Year & Sex & $\begin{array}{c}\text { Maturity } \\
\text { stage }\end{array}$ & df & $a(\mathrm{SE})$ & $b(\mathrm{SE})$ & $r^{2}$ \\
\hline All & All & All & 18,101 & $0.02(0.00)$ & $2.89(0.01)$ & 0.98 \\
All & F & All & 8588 & $0.02(0.00)$ & $2.93(0.01)$ & 0.97 \\
All & M & All & 9511 & $0.05(0.00)$ & $2.63(0.01)$ & 0.97 \\
All & All & J & 5075 & $0.02(0.00)$ & $2.90(0.01)$ & 0.98 \\
All & All & A & 1,2941 & $0.02(0.00)$ & $2.82(0.02)$ & 0.98 \\
2015 & F & All & 3323 & $0.01(0.00)$ & $3.06(0.01)$ & 0.97 \\
2016 & F & All & 1100 & $0.03(0.00)$ & $2.78(0.02)$ & 0.98 \\
2017 & F & All & 1487 & $0.02(0.00)$ & $2.86(0.02)$ & 0.99 \\
2018 & F & All & 1613 & $0.02(0.00)$ & $2.90(0.02)$ & 0.99 \\
2019 & F & All & 1057 & $0.02(0.00)$ & $2.90(0.02)$ & 0.99 \\
2015 & M & All & 3923 & $0.01(0.00)$ & $3.02(0.01)$ & 0.97 \\
2016 & M & All & 1406 & $0.03(0.00)$ & $2.74(0.02)$ & 0.97 \\
2017 & M & All & 1595 & $0.03(0.00)$ & $2.77(0.02)$ & 0.98 \\
2018 & M & All & 1461 & $0.02(0.00)$ & $2.87(0.01)$ & 0.97 \\
2019 & M & All & 1118 & $0.02(0.00)$ & $2.90(0.01)$ & 0.98 \\
& & & & & & \\
\hline
\end{tabular}

in the NGC occurs during a transient spawning aggregation (Domeier, 2012). Additionally, spawning aggregations of Pacific hake have a male-biased sex ratio, as has been reported for the offshore population of Pacific hake (Saunders and McFarlane, 1997). Several explanations have been proposed for this phenomenon in other hake species, including early arrival and late departure of males to the spawning ground, females spawning in midwater and a consequently higher proportion of males at the bottom, and a biological strategy to ensure fecundation (Botha, 1986; Di Giácomo et al., 1993; Pájaro et al., 2005; Bustos et al., 2007; Korta et al., 2015).

It is essential to note that the sampling period (and the fishing season for Pacific hake) begins once fishermen obtain high catch rates and once Pacific hake reach commercial size ( $>40 \mathrm{~cm}$ SL). The season ends once the catch rate and mean SL diminish to unprofitable levels. Given the low ex-vessel prices of Pacific hake, with an average price of $\$ 0.61 / \mathrm{kg}$ (in 2019 U.S. dollars) during the study period, the profitability of the fishery for Pacific hake depends on achieving high catch rates with low fishing effort (i.e., few fishing days). In addition, the presence of other aggregated and more highly valued finfish species, such as the Gulf croaker (Micropogonias megalops), for which the fishing season occurs during March-August (Ramírez-Rodríguez, 2017; Arzola-Sotelo et al., 2018), could offer a concomitant explanation for the shift in the species targeted by the trawler fleet during the spring.
A pattern of catch rates of Pacific hake decreasing during January-March has been observed in other studies in the Gulf of California (Mathews et al., 1974; Grande-Vidal, 1983; Godínez-Pérez, 2016). The reduction in the catch rates in this study and in these other studies could be related to the end of the spawning aggregation of Pacific hake in the NGC. The progressive absence of large (in length and weight) adults reduces the number of individuals of Pacific hake in the fishing grounds and the mean size of the fish caught.

In the NGC, the high concentrations of larvae of Pacific hake are related to the ephemeral presence of an anticyclonic eddy during winter (Sánchez-Velasco et al., 2009). The presence of this eddy seems to influence the spawning areas of other fish species that inhabit the Gulf of California (Contreras-Catala et al., 2012). Therefore, the spawning areas of Pacific hake could be associated with the winter eddy in this zone. The influence of oceanographic structures on spawning areas has been reported for other hake species (Di Giácomo et al., 1993; Marrari et al., 2019).

Results from previous studies indicate that at depths $>100 \mathrm{~m}$, winter temperatures $\left(<18^{\circ} \mathrm{C}\right)$ in the $\mathrm{NGC}$ remain vertically homogeneous (Lavín and Marinone, 2003). Water temperature homogeneity might partially explain the absence of a clear depth-dependent profile of catch rate or mean SL because the fleet deploys trawl nets at depths $>200 \mathrm{~m}$ during the daytime, when fish have been 


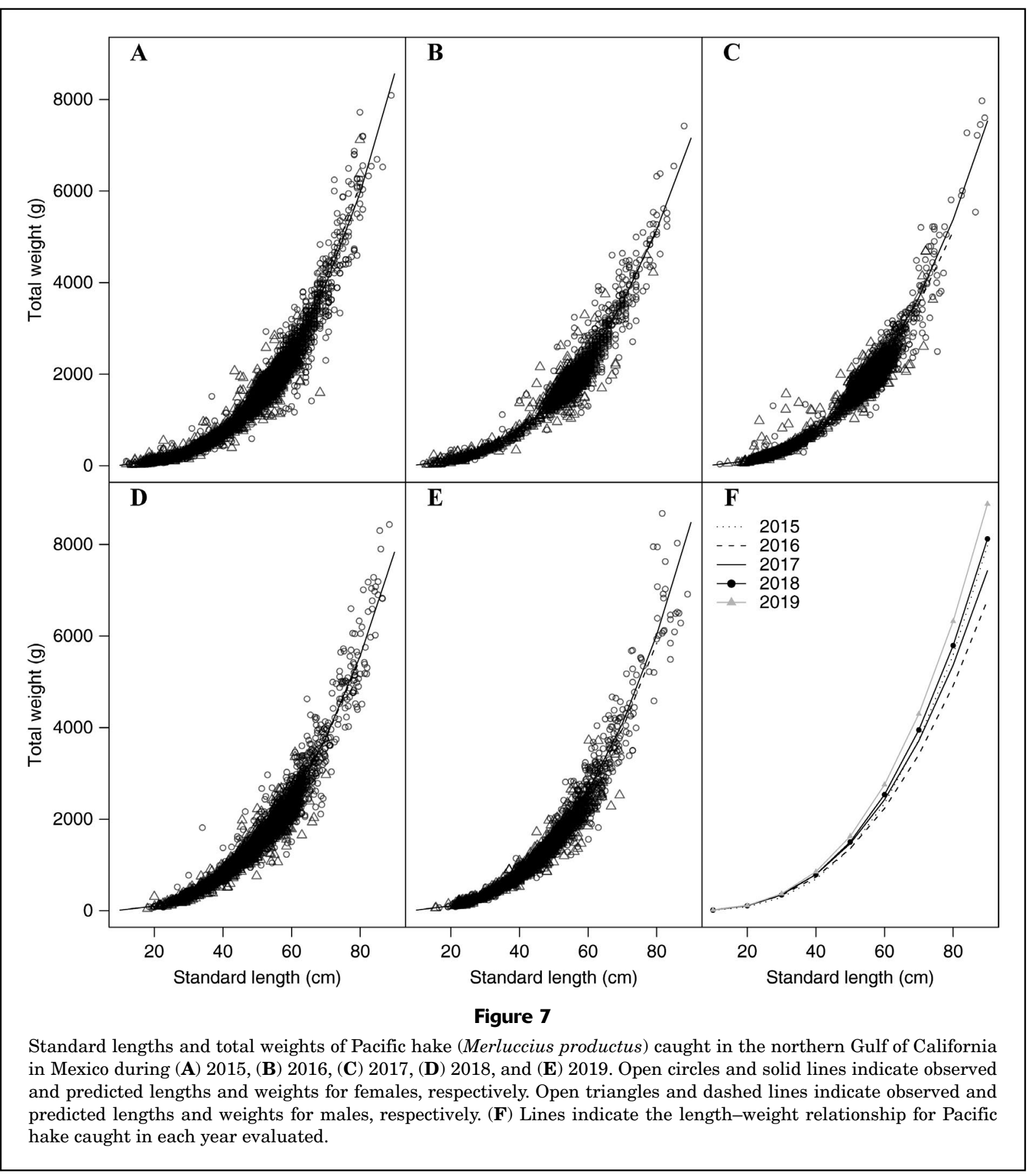

observed to migrate nearer to the bottom (Godínez-Pérez, 2016). Diel vertical migration has been reported for Pacific hake in other regions (Hamel et al., 2015).

Winter spawning of Pacific hake has been reported for other populations in the eastern Pacific Ocean (Saunders and McFarlane, 1997). However, slight differences exist between the spawning time and sites of Pacific hake from the NGC and those for Pacific hake from the coastal stock and from Baja California Sur. The Pacific hake in the coastal stock spawn during January-March several kilometers offshore (Agostini et al., 2006), and Pacific hake from Baja California Sur spawn during February-May, peaking in May (Balart-Páez, 2005). Pacific hake in NGC spawn only during DecemberMay, peaking in December-February (Denton-Castillo, 2018). The difference in spawning times and sites between these stocks could serve as a gene flow barrier that fosters the genetic isolation indicated by results of other studies (Iwamoto et al., 2015; García-De León et al., 2018). 


\section{Table 5}

Transformed standard lengths (SLs) reported in the literature for Pacific hake (Merluccius productus), by source, sex, season, region, and original type of length measurement (total length [TL], fork length [FL], or SL). Regions used in sources include Canada (CAN), Strait of Georgia (SG), Vancouver Island (VI), Washington (WA), Oregon (OR), California (CA), Baja California Sur (BCS), and the northern, central, and southern Gulf of California (NGC, CGC, and SGC).

\begin{tabular}{|c|c|c|c|c|c|c|}
\hline \multicolumn{2}{|c|}{$\mathrm{SL}(\mathrm{cm})$} & \multirow[b]{2}{*}{ Sex } & \multirow[b]{2}{*}{ Season } & \multirow[b]{2}{*}{ Region } & \multirow{2}{*}{$\begin{array}{l}\text { Original } \\
\text { length } \\
\text { type }\end{array}$} & \multirow[b]{2}{*}{ Source } \\
\hline Range & Mean & & & & & \\
\hline$\leq 62.3$ & 48.2 & $\mathrm{~F}$ & All & $\mathrm{CA}$ & TL & Best (1963) \\
\hline$\leq 54.0$ & 44.9 & $\mathrm{M}$ & All & CAN, WA, OR, CA & TL & Alverson and Larkins (1969) \\
\hline $24.2-65.7$ & 42.3 & All & & & & \\
\hline $9.5-61.3$ & - & All & & & & \\
\hline $9.5-72.2$ & - & $\mathrm{F}$ & Spring-summer & CA, OR, WA & FL & Dark (1975) \\
\hline $9.5-59.5$ & - & M & & & & \\
\hline $9.2-28.7$ & 16.7 & All & Spring & CGC-SGC & TL & Mathews (1975) \\
\hline $15.9-88.1$ & - & All & All & NGC & TL & Mathews (1985) \\
\hline $9.5-72.2$ & 39.5 & All & All & SG & FL & McFarlane and Beamish (1985) \\
\hline $37.7-63.6$ & 42.8 & All & & & & \\
\hline $37.7-67.7$ & 46.8 & $\mathrm{~F}$ & All & VI & FL & Beamish and McFarlane (1985) \\
\hline $37.7-59.5$ & 49.0 & M & & & & \\
\hline $11.7-53.2$ & 33.6 & All & Spring & WA, OR, CA & TL & Stepanenko (1989) \\
\hline- & 41.2 & $\mathrm{~F}$ & Winter & WA, OR, CA & FL & Saunders and McFarlane (1997) \\
\hline- & 40.2 & $\mathrm{M}$ & & & & \\
\hline $7.5-33.5$ & 17.3 & All & All & BCS & SL & Balart-Páez (2005) \\
\hline $32.5-40.7$ & 40.7 & All & Spring & NGC & TL & Mazorra-Manzano et al. (2008) \\
\hline- & 34.9 & $\mathrm{~F}$ & Summer & & & \\
\hline- & 33.0 & M & & & & \\
\hline- & 35.0 & $\mathrm{~F}$ & Fall & $\mathrm{CAN}$ & FL & King et al. (2012) \\
\hline- & 27.4 & $\mathrm{M}$ & & & & \\
\hline- & 30.4 & $\mathrm{~F}$ & Winter & & & \\
\hline - & 25.9 & $\mathrm{M}$ & & & & \\
\hline $10.4-81.5$ & & All & Winter & NGC & TL & Godínez-Pérez (2016) \\
\hline $11.9-89.2$ & 47.4 & All & & & & \\
\hline $11.9-89.2$ & 50.0 & $\mathrm{~F}$ & Winter-spring & NGC & SL & This study \\
\hline $11.9-79.9$ & 45.0 & $\mathrm{M}$ & & & & \\
\hline
\end{tabular}

Our results indicate that Pacific hake in the NGC present sex dimorphism because adult females had greater maximum lengths, weights, and allometric coefficients than males. These findings are similar to those of other studies that observed differences in size at age after sexual maturity (Dark, 1975; Mathews, 1975; Francis, 1983; Balart-Páez, 2005; King et al., 2012). Additionally, the maximum size that has been reported for Pacific hake was observed in the NGC in this study (Table 5).

In all years except 2015, the allometric coefficient was lower than 3 but above the threshold of a $b$ value of 2.5 that Pauly (1984) and Froese et al. (2011) considered an indication of negative allometric growth. Furthermore, we did not find differences in the LWR between maturity stages, indicating that length and weight increase proportionally throughout the life of Pacific hake. In this regard, the variability of the allometric coefficient could be interpreted as seasonal growth in weight, as suggested by Bailey et al. (1982). They found that Pacific hake lose $5-10 \%$ of total weight during their spawning season (because of inanition) and gain 11-30\% during their feeding season. Unfortunately, because all Pacific hake were sampled during winter (spawning season) and no stomachs were collected in our study, it was not possible to provide evidence of seasonal changes in weight.

Our data indicate that there was no effect of mesh size on mean SL. Homogeneity in mean SL can be explained by smaller individuals escaping because of the mesh size of nets and then, once the net becomes clogged with large individuals, selectivity of nets remaining constant. Likewise, the low abundance of fish in the size class of 30-45 cm SL during 2015-2017 might be evidence of a size-dependent migratory pattern, ontogenetic differences in their spatial distribution, or interannual variability of abundance and distribution linked to environmental conditions (Agostini et al., 2008).

Although these results shed light on the basic biology and fishery of the Pacific hake in the NGC, future studies should address management questions to foster sustainable development. Although population characteristics, such as age structure, growth, maturity, and mortality, and fisheries ecology remain poorly understood for this 
species in the NGC, data-limited stock assessments could provide temporary reference points for management.

The maximum size of Pacific hake in the NGC $(108.8 \mathrm{~cm}$ TL) is at least 3-fold of that reported for Pacific hake in the southern Gulf of California and Baja California Sur $(33.5 \mathrm{~cm}$ TL), and information about that stock is very limited (Mathews, 1975; Balart-Páez, 2005; Salinas-Mayoral, 2018). In the short term, focusing commercial fishing for Pacific hake on the NGC is a potential management strategy.

As a precautionary measure, the specification that only vessels licensed to take Pacific hake can take individuals of this species in the NGC could help to eliminate fishing effort over the currently allowed level that is a result of illegal, or incidental, catch by other ships that fish in the NGC. In future research, particular attention must be set on examining the possible adverse effects of fishing over a reproductive aggregation.

\section{Acknowledgments}

The generous collaboration of the fishing companies of the hake fishery made this study possible. We thank the Posgrado en Ciencias del Mar y Limnología and Consejo Nacional de Ciencia y Tecnología for financial support and the Facultad de Ciencias del Mar for logistical support. This study is based on an observer program that is funded by the Environmental Defense Fund, the David and Lucile Packard Foundation, the alliance of the World Wildlife Fund and Carlos Slim Foundation, and the Walton Family Foundation. We are grateful to the observers who worked on board vessels in the fishery for Pacific hake, especially the late E. Estrada Alemán. Comments made by the reviewers are appreciated.

\section{Literature cited}

Aceves-Medina, G., S. P. A. Jiménez-Rosenberg, A. HinojosaMedina, R. Funes-Rodríguez, R. J. Saldierna-Martínez, and P. E. Smith.

2004. Fish larvae assemblages in the Gulf of California. J. Fish Biol. 65:832-847. Crossref

Agostini, V. N., R. C. Francis, A. B. Hollowed, S. D. Pierce, C. Wilson, and A. N. Hendrix.

2006. The relationship between Pacific hake (Merluccius productus) distribution and poleward subsurface flow in the California Current System. Can. J. Fish. Aquat. Sci. 63:2648-2659. Crossref

Agostini, V. N., A. N. Hendrix, A. B. Hollowed, C. D. Wilson,

S. D. Pierce, and R. C. Francis.

2008. Climate-ocean variability and Pacific hake: a geostatistical modeling approach. J. Mar. Syst. 71:237-248. Crossref

Alverson, D. L., and H. A. Larkins.

1969. Status of the knowledge of the Pacific hake resource. CalCOFI Rep. 13:24-31.

Arzola-Sotelo, E. A., J. López-Martínez, C. H. Rábago-Quiroz,

J. G. Padilla-Serrato, and E. Morales-Bojórquez.

2018. Population dynamics of the bigeye croaker Micropogonias megalops in the northern Gulf of California. CalCOFI Rep. 59:86-101.
Bailey, K. M., R. C. Francis, and P. R. Stevens. 1982. The life history and fishery of Pacific whiting, Merluccius productus. CalCOFI Rep. 23:81-98.

Balart-Páez, E. F.

2005. Biología y ecología de la merluza bajacaliforniana Merluccius angustimanus Garman, 1899, en la costa occidental de Baja California Sur, México. Ph.D. diss., 158 p. Univ. Aut. Nuevo León, Monterrey, Mexico. [In Spanish.]

Beamish, R. J., and G. A. McFarlane.

1985. Pacific whiting, Merluccius productus, stocks off the west coast of Vancouver Island, Canada. Mar. Fish. Rev. 47(2):75-81.

Benson, A. J., G. A. McFarlane, S. E. Allen, and J. F. Dower.

2002. Changes in Pacific hake (Merluccius productus) migration patterns and juvenile growth related to the 1989 regime shift. Can. J. Fish. Aquat. Sci. 59:1969-1979. Crossref

Best, E. A.

1963. Contribution to the biology of the Pacific hake, Merluccius productus (Ayres). CalCOFI Rep. 9:51-56.

Botha, L.

1986. Reproduction, sex ratio and rate of natural mortality of Cape hakes Merluccius capensis Cast. and M. paradoxus Franca in the Cape of Good Hope area. S. Afr. J. Mar. Sci. 4:23-35. Crossref

Burnham, K. P., and D. R. Anderson.

2004. Multimodel inference: understanding AIC and BIC in model selection. Sociol. Methods Res. 33:261-304. Crossref

Bustos, C. A., F. Balbontín, and M. F. Landaeta.

2007. Spawning of the southern hake Merluccius australis (Pisces: Merlucciidae) in Chilean fjords. Fish. Res. 83:23-32. Crossref

Contreras-Catala, F., L. Sánchez-Velasco, M. F. Lavín, and V. M. Godínez.

2012. Three-dimensional distribution of larval fish assemblages in an anticyclonic eddy in a semi-enclosed sea (Gulf of California). J. Plankton Res. 34:548-562. Crossref

Dark, T. A.

1975. Age and growth of Pacific hake, Merluccius productus. Fish. Bull. 73:336-355.

Denton-Castillo, J.

2018. Agregaciones y aspectos reproductivos de la merluza Merluccius productus (Ayres, 1855) en el centro y norte del Golfo de California. M.S. thesis, 109 p. Univ. Aut. Sin. Mazatlan, Mexico. [In Spanish.]

Di Giácomo, E. E., J. Calvo, M. R. Perier, and E. Morriconi.

1993. Spawning aggregations of Merluccius hubbsi, in Patagonian waters: evidence for a single stock? Fish. Res. 16:9-16. Crossref

DOF (Diario Oficial de la Federación).

2018. Acuerdo por el que se da a conocer la actualización de la Carta Nacional Pesquera. Diario Oficial Fed. 777(10):1-112 (Segunda Sección). [In Spanish.] [Available from website.]

Domeier, M. L.

2012. Revisiting spawning aggregations: definitions and challenges. In Reef fish spawning aggregations: biology, research and management (Y. S. Mitchenson and P. L. Colin, eds.), p. 1-20. Springer Science and Business Media B. V., Dordrecht, Netherlands.

Francis, R. C.

1983. Population and trophic dynamics of Pacific hake (Merluccius productus). Can. J. Fish. Aquat. Sci. 40:1925-1943. Crossref

Froese, R., A. C. Tsikliras, and K. I. Stergiou.

2011. Editorial note on weight-length relations of fishes. Acta Ichthyol. Piscat. 41:261-263. Crossref 
García-De León, F. J., C. Galván-Tirado, L. S. Velasco, C. A. SilvaSegundo, R. Hernández-Guzmán, I. D. L. A. Barriga-Sosa, P. D. Jaimes, M. Canino, and P. Cruz-Hernández.

2018. Role of oceanography in shaping the genetic structure in the North Pacific hake Merluccius productus. PLoS ONE 13(3):e0194646. Crossref

Grande-Vidal, J. M.

1983. Evaluación biotecnológica de los recursos demersales vulnerables a redes de arrastre de fondo en el golfo de California 1978-1980. Cienc. Pesq. 4:97-125. [In Spanish.]

Grandin, C. J., K. F. Johnson, A. M. Edwards, and A. M. Berger. 2020. Status of the Pacific hake (whiting) stock in U.S. and Canadian waters in 2020, 273 p. Prepared by the Joint Technical Committee of the U.S. and Canada Pacific Hake/Whiting Agreement, National Marine Fisheries Service and Fisheries and Oceans Canada. [Available from website.]

Godínez-Pérez, C. A.

2016. Identificación acústica de la merluza del Pacífico norte Merluccius productus en el Golfo de California. M.S. thesis, 132 p. Cent. Interdiscip. Cienc. Mar., Inst. Politéc. Nac., La Paz, Mexico. [In Spanish.]

Guisan, A., T. C. Edwards Jr., and T. Hastie.

2002. Generalized linear and generalized additive models in studies of species distributions: setting the scene. Ecol. Model. 157:89-100. Crossref

Hamel, O. S., P. H. Ressler, R. E. Thomas, D. A. Waldeck,

A. C. Hicks, J. A. Holmes, and G. W. Fleischer.

2015. Biology, fisheries, assessment and management of Pacific hake (Merluccius productus). In Hakes: biology and exploitation (H. Arancibia, ed.), p. 234-262. John Wiley and Sons, West Sussex, UK.

Holden, M. J., and D. F. S. Raitt.

1975. Manual of fisheries science. Part 2: methods of resource investigations and their application. FAO Fish. Tech. Paper 115, 214 p. FAO, Rome.

Iwamoto, E. M., A. E. Elz, F. J. García-De León, C. A. Silva-

Segundo, M. J. Ford, W. A. Palsson, and R. G. Gustafson.

2015. Microsatellite DNA analysis of Pacific hake Merluccius productus population structure in the Salish Sea. ICES J. Mar. Sci. 72:2720-2731. Crossref

King, J. R., G. A. McFarlane, S. R. M. Jones, S. R. Gilmore, and

C. L. Abbott.

2012. Stock delineation of migratory and resident Pacific hake in Canadian waters. Fish. Res. 114:19-30. Crossref

Korta, M., D. García., M. Santurtún, N. Goikoetxea, E. Andonegi,

H. Murua, P. Álvarez, S. Cerviño, J. Castro, and A. Murillas.

2015. European hake (Merluccius merluccius) in the Northeast Atlantic Ocean. In Hakes: biology and exploitation (H. Arancibia, ed.), p. 1-37. John Wiley and Sons, West Sussex, UK.

Lavín, M. F., and S. G. Marinone.

2003. An overview of the physical oceanography of the Gulf of California. In Nonlinear processes in geophysical fluid dynamics (O. U. Velasco-Fuentes, J. Sheinbaum, and J. Ochoa, eds.), p. 173-204. Springer, Drordrecht, Netherlands.

Lloris, D., J. Matallanas, and P. Oliver.

2003. Merluzas del mundo (Familia Merlucciidae). Catálogo comentado e ilustrado de las merluzas conocidas. FAO catálogo de especies para los fines de la pesca 2, 57 p. FAO, Rome. [In Spanish.]

Marín-Enríquez, E., X. G. Moreno-Sánchez., F. J. Urcádiz-Cázares.,

E. Morales-Bojorquez., and J. S. Ramírez-Pérez.

2020. A spatially explicit model for predicting the probability of occurrence of zero-catch quadrants in the tuna purse seine fishery of the Eastern Tropical Pacific Ocean. Cienc. Mar. 46:19-38. Crossref

Marrari, M., G. J. Macchi, B. Santos, and E. Leonarduzzi.

2019. Influence of environmental conditions on the reproductive success and recruitment of the Argentine hake Merluccius hubbsi (southwestern Atlantic Ocean). Fish. Oceanogr. 28:66-81. Crossref

Mathews, C. P.

1975. Some observations on the ecology and the population dynamics of Merluccius angustimanus in the south Gulf of California. J. Fish Biol. 7:83-94. Crossref

1985. Meristic studies of the Gulf of California species of Merluccius, with a description of a new species. J. Nat. Hist. 19:697-718. Crossref

Mathews, C. P., J. L. Granados, and J. Arvizu.

1974. Results of the exploratory cruises of the Alejandro de Humboldt in the Gulf of California. CalCOFI Rep. 17:101-111.

Maunder, M. N., and A. E. Punt.

2004. Standardizing catch and effort data: a review of recent approaches. Fish. Res. 70:141-159. Crossref

Mazorra-Manzano, M. A., R. Pacheco-Aguilar, J. C. RamirezSuarez, and G. García-Sánchez.

2008. Pacific whiting (Merluccius productus) underutilization in the Gulf of California: muscle autolytic activity characterization. Food Chem. 107:106-111. Crossref

McFarlane, G. A., and R. J. Beamish.

1985. Biology and fishery of Pacific whiting, Merluccius productus, in the Strait of Georgia. Mar. Fish. Rev. 47(2):23-34.

Padilla-García, M. A.

1981. Biomasa de sardina (Sardinops sagax) y merluza (Merluccius productus). Febrero, 1977. Cienc. Pesq. 1:35-43. [In Spanish.]

Pájaro, M., G. J. Macchi, and P. Martos.

2005. Reproductive pattern of the Patagonian stock of Argentine hake (Merluccius hubbsi). Fish. Res. 72:97-108. Crossref

Pauly, D.

1984. Fish population dynamics in tropical waters: a manual for use with programmable calculators. ICLARM Stud. Rev. 8, 325 p. Int. Cent. Living Aquat. Resour. Manage., Manila, Philippines.

Peiro-Alcantar, M. T., R. Funes-Rodríguez, R. GonzálezArmas, R. Palomares-García, M. O. Nevárez-Martínez, and B. Shirasago-Germán.

2013. Influence of hydrographic conditions on larval fish assemblage structure in the northern Gulf of California. Rev. Biol. Mar. Oceanogr. 48:535-551. Crossref

$\mathrm{R}$ Core Team.

2019. R: a language and environment for statistical compunting. R Foundation for Statistical Computing, Vienna, Austria. [Available from website, accessed October 2019.]

Ramírez-Rodríguez, M.

2017. A profitability analysis of catch quotas for the Pacific hake fishery in the Gulf of California. North Am. J. Fish. Manage. 37:23-29. Crossref

Ressler, P. H., J. A. Holmes, G. W. Fleischer, R. E. Thomas, and K. C. Cooke.

2007. Pacific hake, Merluccius productus, autecology: a timely review. Mar. Fish. Rev. 69(1-4):1-24.

Ritz, C., and J. C. Streibig.

2008. Nonlinear regression with R, 144 p. Springer, New York. Salinas-Mayoral, C. A.

2018. Dinámica poblacional de la merluza del Pacífico Merluccius productus (Ayres, 1855), en la costa occidental de BCS, 
México. M.S. thesis, 71 p. Cent. Investig. Biol. Noroeste, La Paz, Mexico. [In Spanish.] [Available from website.]

Sánchez-Velasco, L., M. F. Lavín, M. Peguero-Icaza, C. A. LeónChávez, F. Contreras-Catala, S. G. Marinone, I. V. GutiérrezPalacios, and V. M. Godínez.

2009. Seasonal changes in larval fish assemblages in a semi-enclosed sea (Gulf of California). Cont. Shelf Res. 29:1697-1710. Crossref

Saunders, M. W., and G. A. McFarlane.

1997. Observations on the spawning distribution and biology of offshore Pacific hake (Merluccius productus). CalCOFI Rep. 38:147-157.

Silva-Segundo, C. A., M. Brito-Chavarria, E. F. Balart, I. de los A. Barriga-Sosa, R. Rojas-Esquivel, M. I. Roldán, G. Murugan, and F. J. García-De León.

2011. Clarifying the taxonomic status of Merluccius spp. in the northeastern Pacific: a combined morphological and molecular approach. Rev. Fish Biol. Fish. 21:259-282. Crossref
Smith, B. D., G. A. McFarlane, and M. W. Saunders.

1992. Inferring the summer distribution of migratory Pacific hake (Merluccius productus) from latitudinal variation in mean lengths-at-age and length frequency distributions. Can. J. Fish. Aquat. Sci. 49:708-721. Crossref

Stepanenko, M. A.

1989. Distribution, size composition, and abundance of the Pacific hake (Merluccius productus) along the Pacific coast of North America in 1985. In Effects of ocean variability on recruitment and an evaluation of parameters used in stock assessment models (R. J. Beamish and G. A. McFarlane, eds.), p. 81-86. Can. Spec. Publ. Fish. Aquat. Sci. 108. Dep. Fish. Oceans, Ottawa, Canada.

Zar, J. H.

1999. Biostatistical analysis, 4th ed., 663 p. Prentice-Hall, Upper Saddle River, NJ.

Zuur, A., E. N. Ieno., N. Walker., A. A. Saveliev, and G. M. Smith. 2009. Mixed effects models and extensions in ecology with R, 574 p. Springer-Verlag, New York. 